\title{
Hypochondria as a form factor. The role of colonial anxieties as shapers of buildings and urban spaces in British Africa
}

Jacopo Galli

To cite this article: Jacopo Galli (2021): Hypochondria as a form factor. The role of colonial anxieties as shapers of buildings and urban spaces in British Africa, Planning Perspectives, DOI: 10.1080/02665433.2021.1926314

To link to this article: https://doi.org/10.1080/02665433.2021.1926314

曲 Published online: 12 May 2021.

Submit your article to this journal $\pi$

!II Article views: 1

Q View related articles ¿

View Crossmark data \lceil 


\title{
Hypochondria as a form factor. The role of colonial anxieties as shapers of buildings and urban spaces in British Africa
}

\author{
Jacopo Galli (1) a,b \\ ${ }^{a}$ Architecture and Arts Department, Università luav di Venezia, Venice, Italy; ${ }^{\mathrm{b}}$ FEEM Fondazione Eni Enrico Mattei, Milan, \\ Italy
}

\begin{abstract}
The paper explores the role played by hypochondria, defined as the preoccupation with fears of having, or the idea that one has, a serious disease based on the person's misinterpretation of bodily symptoms, in the definition of buildings and urban spaces throughout the history of British presence in the tropics, with a special regard to the African continent. From the medical and hygiene experts to the army engineers and the establishment of Tropical Architecture the relationship with the climatic and health conditions of the tropical belt has triggered fears and anxieties that have often prevented the definition of solutions. This paper shows how the scientific attitude that has characterized the exploration and settlement of tropical areas has not been a steady process but rather a complex mix of fears, false truths, wrong beliefs and slow improvements.
\end{abstract}

\section{KEYWORDS}

Hypochondria; Africa; tropics; medical topography; behaviour

\section{Introduction: the role of hypochondria in the colonial experience}

In a statistical table that appeared in the British Medical Journal in $1913^{1}$ among the reasons why Europeans were invalided while serving overseas in tropical areas malaria, cholera and dysentery are all listed after tropical neurasthenia, a condition that has today completely disappeared from medical dictionaries. The definition of tropical neurasthenia has changed numerous times, but it can be identified as a somatic nervous condition that 'was not psychosis or madness, but was rather an ennui or loss of "edge" brought about by the strains of tropical life, especially the unfamiliar, hot climate. A catch-all for a wide range of symptoms'. ${ }^{2}$ A more precise definition of such a condition today could perhaps be a 'preoccupation with fears of having, or the idea that one has, a serious disease based on the person's misinterpretation of bodily symptoms. (...) The preoccupation causes clinically significant distress or impairment in social, occupational, or other important areas of functioning, ${ }^{3}$; as states the definition of Hypochondria in the fourth edition of the Diagnostic and Statistical Manual of Mental Disorders.

This paper analyses how hypochondria played a key role in shaping the system of relationships that colonial powers established with local populations and territories. Numerous studies such as those of Dane Kennedy and Anderson Warwick, ${ }^{4}$ have dealt with European anxieties in the tropics

CONTACT Jacopo Galli @ jacopogalli@iuav.it

${ }_{1}^{1}$ Greenwood, "Looking Back: The Strange History of Tropical Neurasthenia," 226-7.

${ }^{2}$ Crozier, "What Was Tropical about Tropical Neurasthenia?"

${ }^{3}$ American Psychological Association, Diagnostic and Statistical Manual of Mental Disorders.

${ }^{4}$ See Warwick, Colonial Pathologies; Kennedy, Islands of White; Kennedy, "Diagnosing the Colonial Dilemma."

(c) 2021 Informa UK Limited, trading as Taylor \& Francis Group 
from an historical perspective but the link between urban settlements, architectural elements and hypochondria remains largely unexplored. I will retrace the definition and adaptation of settlement models conducted by British colonizers in light of the evolution of medical theories and their process of transformation into conceptual and practical tools for intervention, considering scientific developments in different fields (medicine, hygiene, building technology, materials, urban and architectural design) and the persistence of hypochondria as two interrelated factors. The process of translating medical theories into urban practices must start from the assumption that 'medical knowledge is always socially constructed and always culture-bound: it is never simply "true"' 5

The main focus of the research will be the African continent even if, since the beginning of the colonial experience, and increasingly during the following centuries of occupation, the complex network of relationships between different parts of the British empire (particularly in the Tropical belt) played a key role in shaping design practices and experimental solutions. The history of British colonial experience is similar and intertwined with other colonial powers but the larger dimension of the network of British domains allowed a higher level of interconnection and exchange of information. The ability of the British empire to be a truly global environment, well before the globalization processes, has recently been doubted and problematized, ${ }^{6}$ but British colonialism allows the observation of complex diachronic conceptual and operative stages ${ }^{7}$ (from the exploration to the occupation and exploitation to the decolonization processes).

The French experience was based on the development of géographie médicale, a mapping of the territory based on medical data that had the unintended result of triggering hypochondria and longstanding misconceptions about ethnicity, location, and diseases. ${ }^{8}$ In Germany tropical medicine was seen as a tool for the acclimatization of German people within the second Reich lebensraum policies that favoured re-settlements in tropical areas ${ }^{9}$ while Dutch colonial enterprises relied heavily on German experts. ${ }^{10}$ In Portugal tropical medicine was strictly linked to religious missionaries while the country promoted international congresses and dialogue to favour scientific exchanges and limit isolation. ${ }^{11}$

The inextricable entanglement between colonial policies and medical developments in different countries and the parallelism between similar processes is witnessed by the very short timeframe for the establishment of global tropical medical schools: 1898 in Great Britain (Liverpool School of Tropical Medicine), 1900 in Germany (Hamburg Institut für Tropenmedizin), 1902 in Portugal (Instituto de Higiene e Medicina Tropical Lisboa), 1905 in the United States (Medical College of Tulane University School of Medicine), 1906 in Belgium (Institut de Médecine Tropicale Brussels), 1907 in France (École du Pharo Marseille) and 1910 in Holland (Koloniaal Instituut Amsterdam).

The basis of this paper is a literary review and archival research which integrates scholarship in urban studies and architecture with relevant research in history of medicine. The chronological span of the research ranges from early examples of XVIth century Euro-African relations to post WWII architects operating in British West Africa until the completion of the independence processes. Its aim is to understand the strict connections and influences between the two fields. The analyses follow the shifts in the type of professional figures that in different periods were

\footnotetext{
${ }^{5}$ Pelling, "The Meaning of Contagion."

${ }^{6}$ Hodges, "The Global Menace," 719-28.

${ }^{7}$ Tilley, "Medicine, Empires, and Ethics in Colonial Africa."

${ }^{8}$ See Osborne, The Emergence of Tropical Medicine in France; Barrett, "The Role of French-Language Contributors to the Development of Medical Geography (1782-1933)," 155-65.

${ }^{9}$ de Souza Correa, "Combating Tropical Diseases in the German Colonial Press."

${ }^{10}$ Teichfischer, "Transnational Entanglements in Colonial Medicine," 63-78.

${ }^{11}$ Amaral, "The Emergence of Tropical Medicine in Portugal," 301-28.
} 
protagonists in the processes of adaptation to tropical conditions, their level of hypochondria and the consequent development of urban and architectural solutions. The first section which is titled 'From idealization to the White man's grave' deals with the first encounters by British explorers and adventurers. The second and third sections, which are dedicated to the discipline of medical topography and to the behaviour of a number of individuals, show the impact of the entwinement of fears and experimental practices of early hygiene experts and amateur scientists. The fourth section, which discusses the emergence of germ theory witnesses the contribution of the first wave of medical experts with the publishing of experimental results and the establishment of medical institutions. The fifth section concerning the endurance of colonial fetishes also highlights the discontinuities in the development of scientific theories and their application and impact on society as a whole. The sixth section analyses the development of building types, or standardized architectural projects, as the torch is passed from medical experts to engineers, specifically those in the military corps, highlighting a shift towards quantitative designs with particular strengths and limitations. The seventh section focuses on the Tropical Building Division, one of the first bodies to foster collaboration between experts in different fields (climatic analyses, construction techniques, materials, etc.). The conclusion traces how the shaping of both urban and individual building spaces became the work of architects and planners. Finally, it examines how this process occurred within a wider context of tropical architecture that can be perceived as a cultural as much as a political movement during the decolonization period, but also as the attempt to establish a design method that was specific to tropical areas and freed from any kind of hypochondria.

\section{The first relationships: from idealization to the White man's grave}

In the first large-scale encounters with Africans, Europeans imagined that they had identified kingdoms very similar to theirs. In 1513 a letter from King Manuel of Portugal to King Afonso of Manikongo (in modern day Angola, Democratic Republic of Congo and Republic of Congo) begins with the same formula with which the king would have addressed a European ruler 'powerful and excellent king of Manikongo'. Equally, Afonso replied 'powerful and excellent prince and king, my brother'. ${ }^{12}$ For a long time, indigenous African architecture was considered as equal to the European one and treated with admiration. In 1668 the Dutch historian Olfert Dapper described with deference the capital of the kingdom of Benin:

the king's palace is a square, and it is as big as the city of Haarlem (...). It is divided into many magnificent palaces, the houses and apartments of the courtiers, and includes long and beautiful galleries, squares, about the size of the Amsterdam Stock Exchange. ${ }^{13}$

Dapper, who had never travelled beyond the narrow borders of Holland, did not therefore experience any fear or anxiety. This suggests that for those interested in seventeenth-century Africa rather than in the history of the European perception of the continent, the illustrative engravings of the buildings have little value. Nonetheless, the African city is described with positive attributions, substantially similar in size and features to its European counterparts. The idealized image of Africa did not originally contain negative meanings; it was a large-scale transposition of the noble savage theories developed in Europe since the fifteenth century (Figure 1). ${ }^{14}$

\footnotetext{
${ }^{12}$ Brásio, Monumenta Missionaria Africana.

${ }^{13}$ Dapper, Naukeurige beschrijvinge der Afrikaensche Eylanden. For a larger analysis of Dapper's legacy see: Jones, "Decompiling Dapper," 171-209.

${ }^{14}$ Ellingson, The Myth of the Noble Savage.
} 


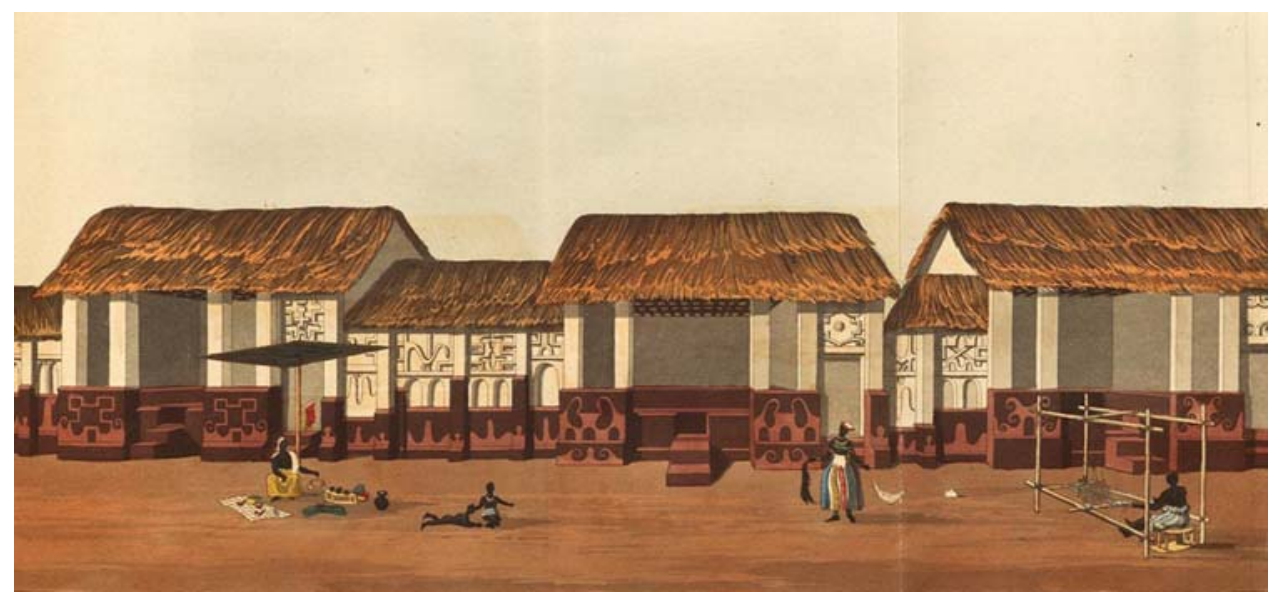

Figure 1. An example of the positive attitude towards the local architecture and urban spaces of Ashantee Architecture from Thomas Edward Bowdich, Mission from Cape Coast Castle to Ashantee (London: Griffith \& Farran, 1819).

Such idealization is present in British culture as well: William Hodges in the book Travels in India of 1793 affirms the substantial equality of the different architectural forms, given by the common origin. The statement criticizes the superiority of the Greek hut as the only correct model, a thesis supported by Marc-Antoine Laugier. Hodges states:

One natural inference may and ought to be drawn from what has been said, that the several species of stone buildings which have been brought more or less to perfection, instead of being copies of each other are essentially the same, the spontaneous produce of genius in different countries, the necessary effects of similar necessity and materials older and younger brothers and sisters of the same family. ${ }^{15}$

In 1819, in his account of an expedition to Ashanti land, Edward Bowditch describes in great detail the magnificence and originality of the court of the local king. ${ }^{16}$ The idealization of Africa, that continued for centuries despite the progressive increase of contacts and commercial relationships, was partly due to the lack of detailed knowledge of the immense internal territories; in the early XIXth century, after three centuries of coastal exploration, Europeans had occupied only a few bridgeheads, mainly ports and islands. ${ }^{17}$

The incremental occupation of the continent built a completely reversed perspective: the utopian and positivist vision declined and gave way to the disturbing nickname of 'White Man's Grave' a term that was first used to describe Sierra Leone, which became the first British colony in West Africa in $1807 .{ }^{18}$ The term perfectly synthesized the fears and hypochondria experienced by British colonizers. The medical data available to British doctors through direct observation led to the establishment of a direct link between climate, territory and diseases: Europeans died frequently, and the places where they died were different from their motherlands in terms of average temperatures, geographical characteristics, recurrence of extreme climatic events and related lifestyles of local

\footnotetext{
${ }^{15}$ Hodges, Travels in India During the Years 1780, 1781, 1782, \& 1783, 75-6.

${ }^{16}$ Bowdich, Mission from Cape Coast Castle to Ashantee.

${ }^{17} \mathrm{Few}$ examples can be the island of Goree of the coast of Dakar, Senegal occupied by the Portuguese in 1444 and used as a fortress and slave prison until 1770. In what is today Ghana Europeans (Dutches, Danishes, Swedish, Portuguese, British) constructed 19 fortresses between the XVI and XVII centuries.

${ }^{18}$ See Rankin, The White Man's Grave. For a critical assessment see Curtin, "The White Man's Grave," 94-110.
} 
people. ${ }^{19}$ There had to be a correlation between climate and mortality: 'since the tropical climate and environment was new to the colonial foreigners, these received the brunt of the blame for causing sickness disease and death. Environment and health, in the western mentality were symbiotic' ${ }^{20}$ The apparent immunity of Africans to disease generated a further false belief: black peoples had to be biologically different from whites and could live and work all their lives in the tropical areas, unlike Europeans, who had no chance of acclimatization and long-term survival. ${ }^{21}$

\section{Medical topography, a scientific approach to the territory}

The first major wave of colonial occupation of the African continent occurred at the beginning of the XIXth century. It inextricably linked medical science, urban settlements and political and social mechanisms ${ }^{22}$ through the construction of a series of tools that would shape the European experience in tropical areas for centuries. The conceptual and operative tools established and applied to cope with the climatic and geographical conditions show how scientific experimental approaches and hypochondriac anxieties were two complementary key factors in the production of buildings and urban spaces. Miasma theories that explained the illnesses as resultant of the bad air emanating directly from the earth due to heat and humidity were considered the 'scientific truth'. Health was understood to be closely linked to body fluids, the balance of which was easily influenced by temperature. The characteristics of the body and mind of various peoples had been shaped by the climates in which they had developed, with the consequence that emigration to different climates disturbed the balance of liquids in the body, thereby causing diseases. ${ }^{23}$ The precarious health conditions contributed to a construction of Africa as a racially pathological territory. ${ }^{24}$ The climate-disease correlation sets the basis for the development of theories that stated that the minds and bodies of Africans were shaped by the natural environment in which they grew up: Africans were seen as inferior beings because of the climate that did not allow a full development of brain capacity. According to the British explorer, Richard Burton, 'when an African becomes an adult his development stops and from that moment he regresses instead of progressing. ${ }^{25}$ James Lind, who discovered the first cures against scurvy, defined tropical diseases as 'diseases of strangers', ${ }^{26}$ and explained them with a botanical similarity: the effect of the change of climate on a European was the same caused on a plant by the removal from its original land.

The principle controlling and preventative measures advocated by British colonizers within the framework of the miasma theories were medical topography and personal behavioural codes of conduct. This highlights many of the contradictions that characterized the colonial experience: on one side the search for a scientific approach, capable of transforming Africa into a living laboratory $^{27}$ for the experimentation of research solutions, and on the other, the continuous mutual sustaining of hypochondria and irrationality. The discipline of 'medical topography' ${ }^{28}$ is based on a

\footnotetext{
${ }^{19}$ On the issue of the construction of the tropical diversity see Driver and Martins, Tropical Vision in the Age of Empire.

${ }^{20}$ Savage, Western Impression of Nature and Landscape, 152.

${ }^{21}$ On the issue of acclimatization see Harrison, Climates and Constitutions; Kenny, "Climate, Race, and Imperial Authority," 694-714.

${ }^{22}$ For more info on the role played by medicine in the formation of the British Empire see: Curtin, Disease and Empire; Farley, Bilharzia: $A$ History of Imperial Tropical Medicine; Macleod and Lewis, Disease, Medicine, and Empire.

${ }^{23}$ Harrison, Climates and Constitutions, 60-1.

${ }^{24}$ Smith, The History of Tropical Medicine, 16.

${ }^{25}$ The quote is taken from Cairns, Prelude to Imperialism, 85.

${ }^{26}$ Lind, An Essay on Diseases Incidental on Europeans in Hot Climates.

${ }^{27}$ Tilley, Africa as a Living Laboratory.

${ }^{28}$ As an example an accurate study of West African topography is provided in Boyle, A Practical Medico-Historical Account of the Western Coast of Africa.
} 
detailed empirical observation of the tropical regions to understand the places where the diseases were more or less common. With these data sets, the Europeans could proceed with an appropriate positioning of the urban settlements. In some cases, the information was accurate and useful: they knew, for example, that islands and mountains were healthier than the coasts. At other times, the choice was less scientific: the areas where yellow fever did not erupt for a long time automatically had a better climate. A map of the Kilimanjaro area published in The Arab and the African by Triste Pruem in $1891^{29}$ shows the discipline of medical topography applied on a specific geographical support. Large parts of the map are depicted in white and labelled with clear dangers such as 'very little water', 'region of tse tse fly', 'marshy coast swamp' while a significantly smaller portion of the land is considered safe for European settlements and labelled with heights and physical characteristics (Figure 2).

This scientific-experimental method, although extremely simplified, shows the willingness to adapt to the African territory not starting from simple geographical information but from a series of experimental data derived from direct observation. It is an attempt at an anti-folkloric description of Africa as a territory made of difficult climatic and health conditions that can be analyzed and described in order to address them in the best possible way. At this stage, no planning solutions were provided, nor was there any consideration of the urban form and architectural characteristics of the settlements. The first rudimentary considerations about the orientation of the buildings that could potentially lead to the shaping of urban settlements are provided in the manual Treatise on Tropical Diseases on Military Operations, published in 1804 by Benjamin Moseley, one of the main proponents of the miasma theories:

The aspect of a house may be towards any other quarter than the West [...] If it range from East to West, the morning and evening sun will have less surface to act on, and the building must necessarily be cooler; as the meridional sun acts nearly the same on the roof, let it be placed how it may. But the East should not be excluded on account of the breeze, and the afternoon shade and coolness; then, if the building be single, a North front, with windows, piazza, and balcony to the East and South, has the advantage. $^{30}$

Simple indications were deduced from the direct observation of climatic phenomena, and supported by experiments in order to provide basic design guidelines.

\section{Personal behaviour, applied hypochondria}

In Moseley's book only a few prescriptions are based on experimental observation of climate and environment. By far the largest part of the treatise is devoted to a series of personal conduct prescriptions, seen as the most valuable method of disease prevention by the theorists of miasma medicine. The prescriptions, which vary among various authors, refer to the spirit of European puritanism: rapid changes in temperature were to be avoided, and a particular emphasis was placed on perspiration; wearing flannel, a soft woven fabric made of wool or cotton, on the skin was extremely important in order to prevent shivering. ${ }^{31}$ The most common rule, however, was moderation in behaviour and emotions: physical exercise, particularly in the heat of the day, mental exercise, excessive joy or pain, all the pleasures of the body had to be drastically limited; wines and liqueurs, sexual relations and consumption of meat were considered dangerous. Anxiety was established as a permanent condition leading to strict separation and open racism. Although scarcely effective,

\footnotetext{
${ }^{29}$ Pruem, The Arab and the African.

${ }^{30}$ Moseley, Treatise on Tropical Diseases on Military Operations, 58.

${ }^{31}$ Renbourn, "The History of the Flannel Garment and Cholera Belt," 211-25.
} 


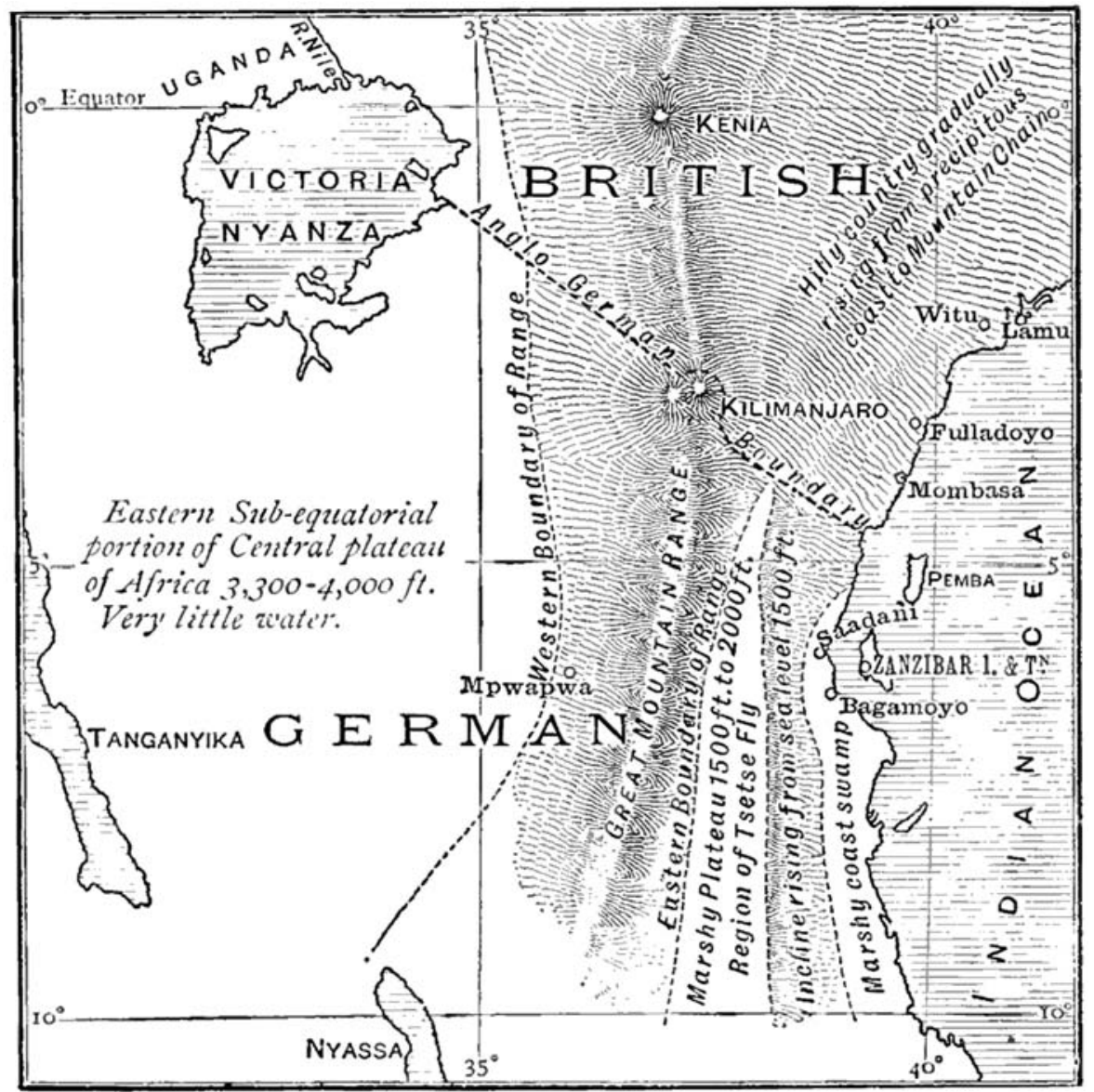

Figure 2. Map of the Kilimanjaro area from Tristem Pruem, The Arab and the African (London: Seeley and Co., 1891).

behavioural codes had an important psychological influence on the formation of the European idea of the tropics. ${ }^{32}$ These prescriptions led to a clear separation between European and Africans, which reinforced the correlation between climate and racial differences and the description of the Africans as inferior and animalistic. Benjamin Moseley describes in these terms the enslaved Africans who were forced to labour on plantations: 'a cold, damp, smoky hut, for his habitation; snakes and lizards his companions; crude, viscid food, and bad water, his only support'. ${ }^{33}$

Miasma theories played a fundamental role in shaping the vision of Africa and the tropics as 'other'. A vision that characterized the entire XIXth century and was not mitigated by the increasing direct experience of the continent. The vast majority of the XIXth century geographical explorers are the perfect example of the firm belief in a presumed environmental and biological diversity between Europeans and other populations. To them the enormous African hinterland was an unexplored territory, a laboratory that needed to be studied and analyzed in ways which, allegedly, only Europeans could, because Africans 'even then quickened by foreign influences, never built-up

\footnotetext{
${ }^{32}$ Curtin, "The White Man's Grave," 94-110.
}

${ }^{33}$ Moseley, Medical Tracts. 
anything approaching a real civilization'. ${ }^{34}$ Africa offered immense research possibilities. In conjunction, the desire to replace the supposed superstitions of local peoples with what was considered to be Western reason supported by science, a science that was nothing more than organized knowledge or trained common sense, made mainly by amateurs and that advanced thanks to sudden discoveries and inexorable denials, sensationalism, false truths and hypochondria. ${ }^{35}$

The vision of Africa as otherness, a deforming mirror of Europe, is a way of addressing the continent that partially still survives today - a mixture of fascination, adventure and sense of superiority that has always permeated the spirit of the explorer, the scientist and the Western merchant. In Orientalism of 1987, Edward Said identifies the idea of European identity rooted in a superiority with respect to other peoples and other cultures. Medical theories were therefore a fundamental basis in the creation of an image of Africa painted by British prime minister Arthur Balfour in 1910 in a speech to the House of Commons 'as something one judges (as in a court of law), something one studies and depicts (as in a curriculum), something one disciplines (as in a school or prison), something one illustrates (as in a zoological manual)'. ${ }^{36}$

The miasma theories indelibly marked the relations between European colonizers and Africans between the end of the XIXth and the beginning of the XXth century. Despite discoveries of the bacteriological nature of malaria, cholera and yellow fever, ${ }^{37}$ in the last decades of the nineteenth century, no less emphasis was placed on the description of the tropics as a hostile environment. Tropical medicine experts continued for much of the XXth century to describe the tropics as alien to massive European colonizations, linking disease to socially constructed geographical and racial phenomena. ${ }^{38}$ It can even be said that the relationship worsened: if hygiene experts as Lind and Moseley, while warning of the enormous dangers, supported the possibility of adaptation to the climate, other late XIXth century scholars postulated the impossibility for white men to live in the tropics, linking it to the growing belief of a European racial superiority and to a consequent biological difference. ${ }^{39}$ Benjamin Kidd, one of the most influential sociologists of the Victorian era, describes this condition with a shrewd metaphor:

In the tropics the white man lives and works only as a diver lives and works under water. Alike in a moral, in an ethical and in a political sense, the atmosphere he breaths must be that of another region.

Neither physically, nor morally, nor politically can he be acclimatised in the tropics. ${ }^{40}$

Living in the tropics was compared to drowning: hypochondria had definitely been established as the main factor influencing personal behaviour and the construction of a whole system of relationships.

\section{The emergence of germ theory and the persistence of hypochondria}

The last years of the XIXth century witnessed the definitive development of tropical medicine and its culmination, in 1898, with the establishment of the Liverpool School of Tropical Medicine, followed in 1899 by the London School of Tropical Medicine. ${ }^{41}$ The establishment of tropical medicine

\footnotetext{
${ }^{34}$ Stoddard, The Rising Tide of Color against the White World Supremacy.

${ }^{35}$ MacKenzie, Imperialism and the Natural World, 5.

${ }^{36}$ Balfour word's are taken from the reinterpretation proposed by Said, Orientalism, 46.

${ }^{37}$ The discovery of the various pathogens of tropical diseases is due to true pioneers of tropical medicine such as Ronald Ross, discoverer of the malaria parasite in mosquitoes, Robert Koch, discoverer of the pathogen of cholera and Carlos Finlay, Cuban doctor, discoverer of the pathogenesis of fever yellow.

${ }^{38}$ Warwick, The Cultivation of Whiteness, 75.

${ }^{39}$ Harrison, Climates \& Constitutions, 87.

${ }^{40} \mathrm{Kidd}$, The Control of the Tropics, 54.

${ }^{41}$ The School of Tropical Medicine founded in 1898 at the University of Liverpool is the first of its kind in the world. Over the years the school has made a fundamental contribution to tropical medicine, particularly through Ronald Ross whose studies on malaria earned
} 
schools reflects major changes resulting from the development of germs theory and discoveries in the fields of parasitology and bacteriology. However, the transition from miasma to germ theory cannot be considered as a clear break even though germ theory was supposed to free Westerners from a hypochondriac vision of Africa since diseases were not a direct consequence of climate and environment, in Africa as in Europe. In reality, a tropical alterity persisted even in the age of germs, the sense of danger merely passed from climate-related hypochondria to hypochondria resulting from the habits and lifestyles of the local populations. ${ }^{42}$ Paradoxically, the perception of British colonizers of indigenous peoples worsened as their supposed backwardness was no longer considered a natural condition caused by the climate but their own fault. In 1919, the chapter dedicated to planning in the book The Maintenance of Health in the Tropics, written by tropical medicine expert W. J. Simpson started with a clear statement:

First, the houses should not be surrounded by nor close to native huts. Native children are seldom infected with malaria, [...] For this reason a dwelling house among native huts is an unhealthy house, apart from the fact that it will also always be in the midst of other insanitary conditions. ${ }^{43}$

The rejection of any local settlement, considered unhealthy, is evident. For Simpson the typical tropical dwelling was a simple bungalow similar to the pre-fabricated houses produced on a large scale in those years by British companies. The very fact that the bungalows were manufactured with metal sheets in Liverpool or Manchester and then shipped to the tropics appeared as a guarantee of health. ${ }^{44}$

In Simpson's manual the technical requirements for the construction of a tropical house are particularly accurate and show a continuous shifting between design decisions taken through experimental approaches and persistence of disproven beliefs, for example one of the first prescriptions presented is the need to raise the ground level from the ground, a direct result of miasma theories that are openly denied in other sections of the book. Simpson describes the ideal tropical dwelling as a two-story house, with important interior heights, space for ventilation between ceiling and roof and a 10/12-foot-deep veranda all around the building. Another possible solution is a central patio for internal distribution. As for the materials, bricks and stone are to be preferred, with wood and corrugated sheet, if properly treated, as an alternative, while the use of local construction techniques such as bamboo or raw earth is inadvisable as a dangerous source of diseases (Figure 3).

Simpson contradicts himself by presenting reports on the results of an experiment conducted by Patrick Manson, unanimously considered the father of modern tropical medicine. ${ }^{45}$ The latter's text shows how it was possible to avoid contracting malaria simply by equipping traditional houses with mosquito nets and a double-door entrance corridor. Manson's experiments show a different conception of the relationship with tropical disease; there a strictly scientific approach no longer tainted by hypochondria can be discerned. Manson argues that, by equipping a traditional dwelling or a new construction with the anti-malaria system he designed, it will be possible to achieve the same results and affirm the substantial equality between Western and local constructions materials and techniques. Hypochondria and scientific approaches overlap and interchange.

the first Nobel Prize awarded to a British person in 1902. The London School of Tropical Medicine was founded by Sir Patrick Manson inside the Albert Dock Seamen's Hospital in London. In 1921, following a donation from the Rockefeller Foundation, the institution took on the current name of London School of Hygiene \& Tropical Medicine.

${ }^{42}$ I take this concept from: Fanon, Le damnes de la terre.

${ }^{43}$ Simpson, The Maintenance of Health in the Tropics, 36.

${ }^{44}$ On the long and complex history of bungalows see: King, The Bungalow: The Production of a Global Culture.

${ }^{45}$ Manson, Tropical Diseases. 


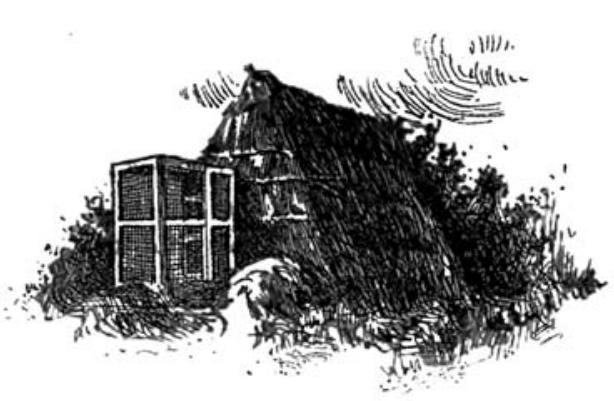

F16. 12.-Mosquito.protecied hut (Celli).

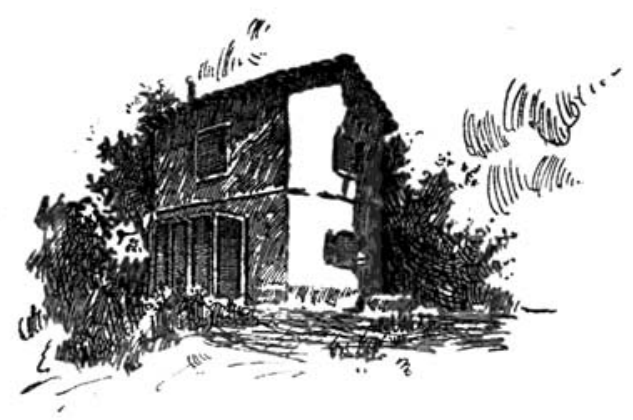

FiG. 13.-Moş2uito.protected ouie (Celli).

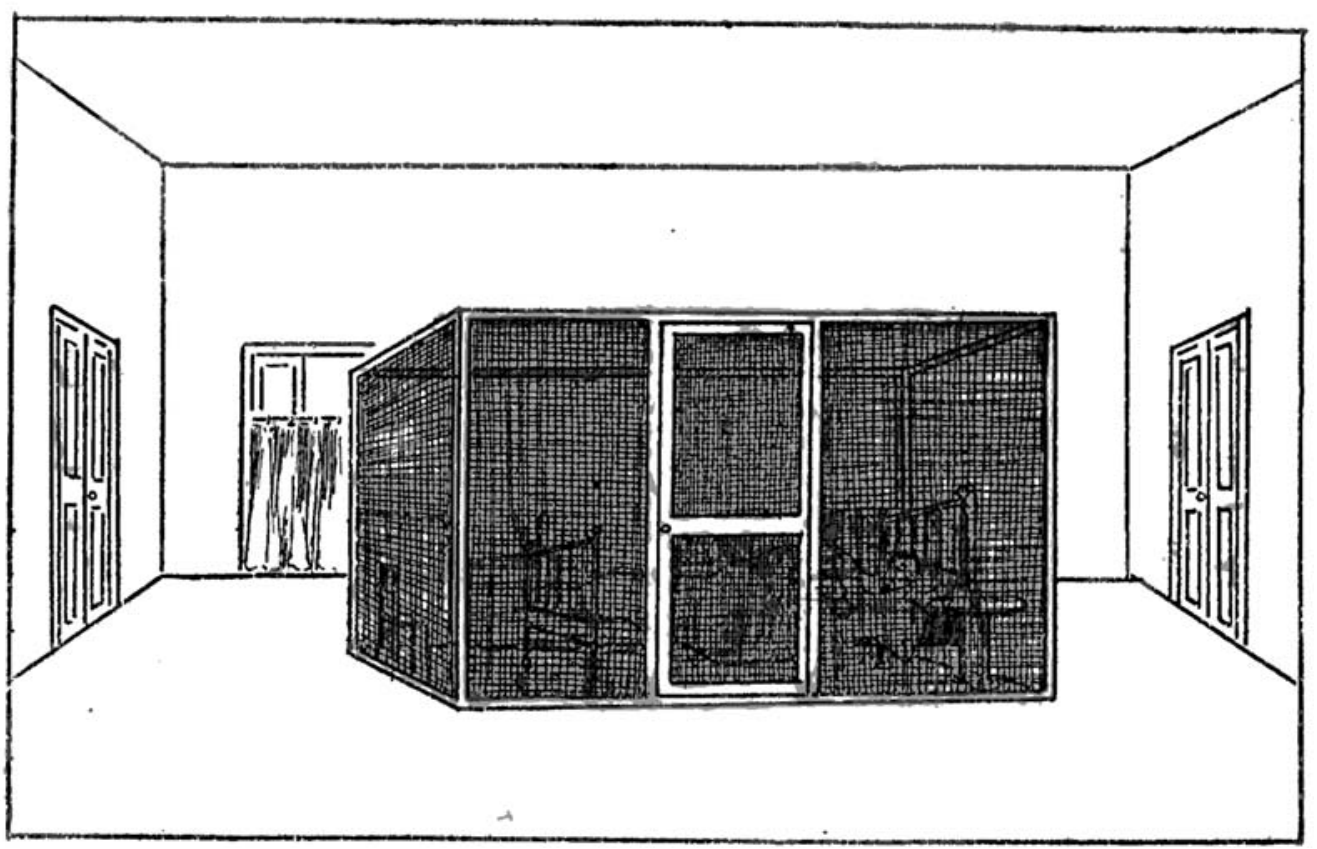

Figure 3. Examples of application of mosquito protection nets in the experiments conducted by Patrick Manson from William John Ritchie Simpson, The Maintenance of Health in the Tropics (London: John Bale, Sons \& Danielsson, 1916).

The work that comes closest to a relationship free of prejudices and hypochondria with the African continent is How to Live in Tropical Africa: a Guide to Tropical Hygiene ${ }^{46}$ by John Murray. Murray opens his study by describing the traditional Zulu hut as a prototypic climatic device. The beehive-shaped circular hut is free of openings and, thanks to thick walls made of organic material, is cool even in the midday sun. The climate data which came from an experiment carried out by the missionary and amateur scientist, Tristram Pruem, was illustrated in the book, The Arab and the African ${ }^{47}$ : a thermometer hanging in the middle of the hut shows a small difference in degrees in the twenty-four hours in each season. After mentioning the hut as a traditional example,

${ }^{46}$ Murray, How to Live in Tropical Africa.

${ }^{47}$ Pruem, The Arab and the African. 
Murray criticizes the typical British bungalow that, although equipped with a veranda and double ceiling, has thin wooden or metal walls that result in the overheating of interior spaces. Murray describes the ideal dwelling as an evolution of the Zulu hut. This consisted of a building formally shaped on the English bungalow but constructed with materials and climatic devices borrowed from the African and Indian tradition. The section of the wall proposed by Murray is particularly noteworthy: the building is raised not on a stone base but on wooden stilts so that air flows freely under the floor. The roof, inclined 45 degrees, comprises two wooden or bamboo frames buffered with organic elements covered with raw earth or cement; in addition, the internal layer is completed with a false ceiling made of carpets (Figure 4).

The roof protrudes about 9-10 feet from the edge of the wall and creates a closed porch with removable bamboo sun-blinds. The internal wall, made with organic material covered with raw earth or cement, is thicker and has openings at different heights: some are real windows overlooking the veranda, others simple ventilation elements that guarantee an adequate cross-ventilation in the rooms. The tropical building is described as the sum and fusion of a series of climatic devices that, if carefully designed and constructed, can guarantee an adequate level of comfort. Moreover, every element was measured and shaped following scientific experiments.

\section{The endurance of Western Fetishes}

In 1898 the Italian-British physician, Luigi Sambon, returning from an expedition to modern day Uganda, presented his work to the Royal Geographical Society by describing the theories about the impossibility of climatic adaptation to the tropics as 'ridiculous'. In his article, 'Remarks on the Possibility of the Acclimatisation of Europeans in the Tropical Regions', of 1897, he wrote:

First, that European emigrants can live and perpetuate their kind in tropical regions; secondly, that the difficulties in the way of colonisation are not due to climate, but to parasitism; thirdly, that acclimatisation is, to a great extent, a mere question of hygiene. If colonisation in the past has proved to be a work of mere destruction, it is not a reason to suppose that it must be so in the future. ${ }^{48}$

In the introduction of Tropical Diseases, a monument to the newfound confidence in tropical medicine, Patrick Manson supported Sambon's conclusions: 'in the tropics as in the temperate climates, in the Europeans and in the natives alike, nearly all diseases are of specific origin, caused by germs'. ${ }^{49}$ Sambon is a great example of the contradictions and hypocrisy of later XIXth-century medical experts: on one side he was promoting a positivist vision of faith in experimental science while at the same time taking advantage of colonial anxieties by designing and producing a fabric composed of a weave of white and coloured thread named 'Solaro', ${ }^{50}$ that he sold as a protective measure against tropical climate. The fabric, which became an iconic feature of British colonialism and is still produced today, was based on the later discredited theory of actinic radiation. This theory, which posited that the tropical sun would cause white skinned populations a variety of nervous disorders, was developed by the American hygiene expert, Charles Edward Woodruff. ${ }^{51}$ Nevertheless, we do not know if Sambon believed in such theories (that contrasted with his own studies) or simply exploited them for financial reasons.

\footnotetext{
${ }^{48}$ Sambon, "Remarks on the Possibility of the Acclimatisation of Europeans in the Tropical Regions," 66.

${ }^{49}$ Manson, Tropical Diseases, 18.

${ }^{50}$ Johnson, "European Cloth and 'Tropical' Skin," 530-60.

${ }^{51}$ Charles Edward Woodruff, physician following the US Army in the Philippine War. He did not possess any type of specific preparation concerning tropical medicine. His theories are presented in Woodruff, The Effects of Tropical Light on White Man.
} 


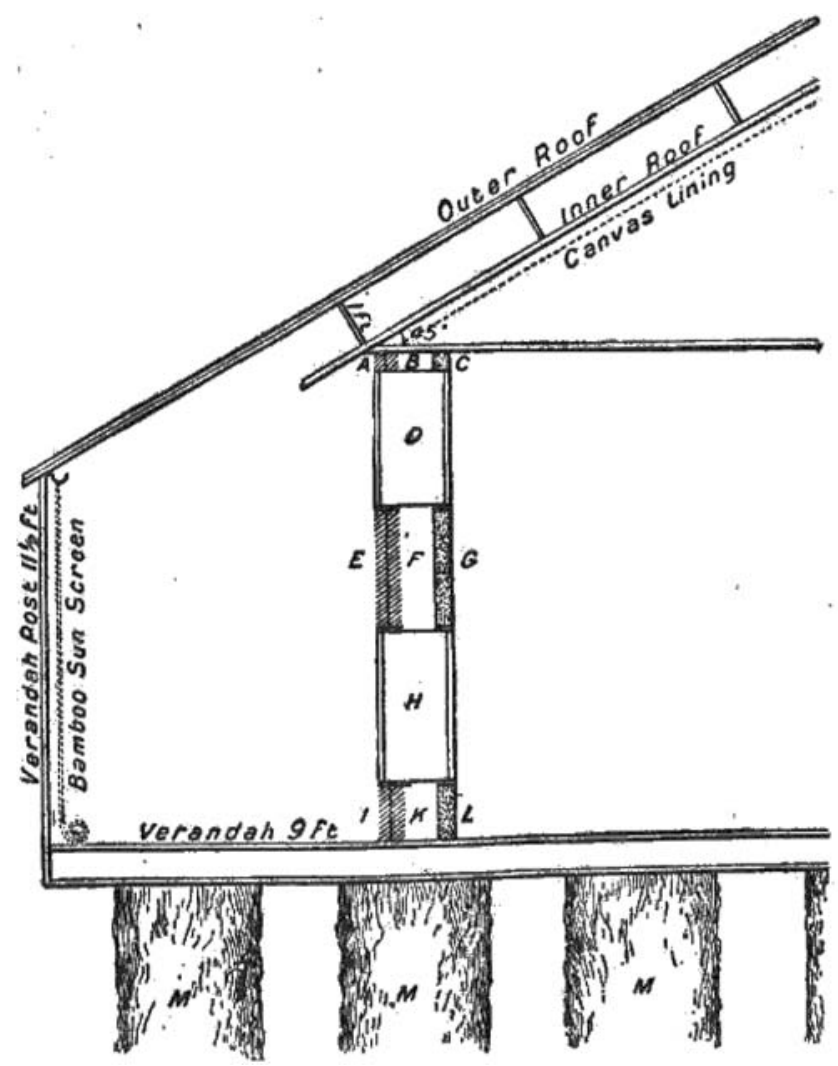

Figure 4. Section of the model of Tropical house from John Murray, How to Live in Tropical Africa (London: Philip \& Son, 1895).

Numerous studies, such as those of Woodruff which gained major global attentions, continued to deny that it was possible for white men to live in the tropics for long periods. As such they reflected the lack of linear correlation between medical-scientific discoveries and political and cultural relations. In Health Preservation in West Africa, tropical hygiene expert, Charles Ryan, states that 'West Africa is, and from the nature of things must be, an unhealthy country for the white race'. ${ }^{52}$ While in 1912 the officer of the Royal Army medical corps Robert James Blackham argued that 'the present-day distribution of civilization supports the view that tropical or subtropical regions are unsuited to the more civilized races'. ${ }^{53}$ Despite the remarkable scientific progresses in the field of medicine, in the first decades of the XXth century hypochondria was still deeply rooted in British culture. ${ }^{54}$ In 1931, Noël Coward, the famous playwright and composer, wrote the song Mad Dogs and Englishmen ${ }^{55}$ in which he described the risks and fears inherent in life in the tropics. Hypochondria was so natural that it became a song theme.

\footnotetext{
${ }^{52}$ Ryan, Health Preservation in West Africa, 6.

${ }^{53}$ Blackman, Aids to Tropical Hygiene, 127.

${ }^{54}$ Kennedy, "The Perils of the Midday Sun: Climatic Anxieties in the Colonial Tropics," 118-40.

${ }^{55}$ The song starts with the words: in tropical climes there are certain times of day when all the citizens retire, to tear their clothes off and perspire. It's one of those rules that the biggest fools obey, Because the sun is much too sultry and one must avoid its ultry-violet ray. Full text is available here: http://www.traditionalmusic.co.uk/folk-song-lyrics/Mad_Dogs_and_Englishmen.htm
} 
The solar topi, a type of pith helmet used in hot climates, quickly became the very symbol of British colonization in the tropics. Ethel Mabuce, a US missionary in Burma between 1916 and 1921, made the helmet the protagonist of her writings, which bear the emblematic title of I Always Wore My Topi. ${ }^{56}$ The helmet was just the aesthetic manifestation of a much deeper problem: white people's need to stand out and protect themselves in order to maintain their otherness from local populations, not for health reason but to continuously reaffirm the colonial social system. Therefore, the solar topi was not only the manifestation of bizarre hypochondriac medical theories but also the symbolic expression of the belief that social and cultural barriers were necessary for the colonizers to preserve their power and privileges. The ritualistic and exclusive use of these objects, such as bungalows and colonial architectures, defined and supported these barriers, to remind both European colonizers and Africans their respective roles. Elspeth Huxley, a wise observer of British colonizers in Kenya, wrote in Out in the Midday Sun

It was no doubt fortuitous that the phasing out of the solar topee (sic) coincided with the decline of the British empire, but believers in a magical basis of the universe might see the topee as an emblem or totem in which strength and confidence of the imperial spirit resided. Fell the totem pole, and you strike at the roots of the tribe, discard the topee and with it goes the belief in the virtue of the imperial mission. ${ }^{57}$

The transformation of climatic devices, originally intended to challenge the difficult conditions through a scientific and experimental approach, into new colonial fetishes, seen as inanimate objects with magical spiritual powers, shows the difficult relation between medical 'truth' and hypochondriac anxieties (Figure 5). Paradoxically, the idea of shaping devices in order to respond to climatic conditions involved not only buildings and urban settlements but also objects such as the solar topi, extravagant elements that despite being disassociated from any kind of scientific explanation were nonetheless shaped through careful studies of form and materials. Hypochondria played a key role in the construction of a physical detachment between European and African and did not allow the colonizers to learn from the precious teachings of the historic African settlements: the high density historic cities of the inland (Timbuktu, Kano, Kumasi, etc.) were replaced by the new coastal capitals (Accra, Lagos, etc.) that by applying at the urban scale the principles of physical separation were shaped as a sum and repetition of bungalows or barracks on a uniform grid. The value of proximity and density as factors which influenced the climatic responsiveness of urban and domestic spaces were completely overlooked.

\section{The development of building types, a quantitative design}

A decisive step towards the end of hypochondria as a central factor in the colonial experience came from the Corps of Royal Engineers, ${ }^{58}$ an organization within the British Army that was appointed to define solutions for constructions and urban problems in the tropical belt. In a long period of time the Royal Engineers defined and developed the Building types system that enabled the construction of military barracks in different geographical regions of the British Empire by adapting a unique set of standardized measures. The decisive step away from hypochondria resulted from the fact that in a still globalizing world a single organization could measure and confront different geographical conditions. The empire facilitated the development of a systematized scientific

\footnotetext{
${ }^{56}$ Mabuce, I Always Wore My Topi. Burma Letters, 1916-21.

${ }^{57}$ Huxley, Out in the Midday Sun.

${ }^{58}$ For a history of Royal Engineers see Weiler, Army Architects; Buchanan, "The Diaspora of British Engineers," 501-24. For an overview on the role of Royal Engineers in the construction of the British Empire see Headrick, The Tentacles of Progress.
} 


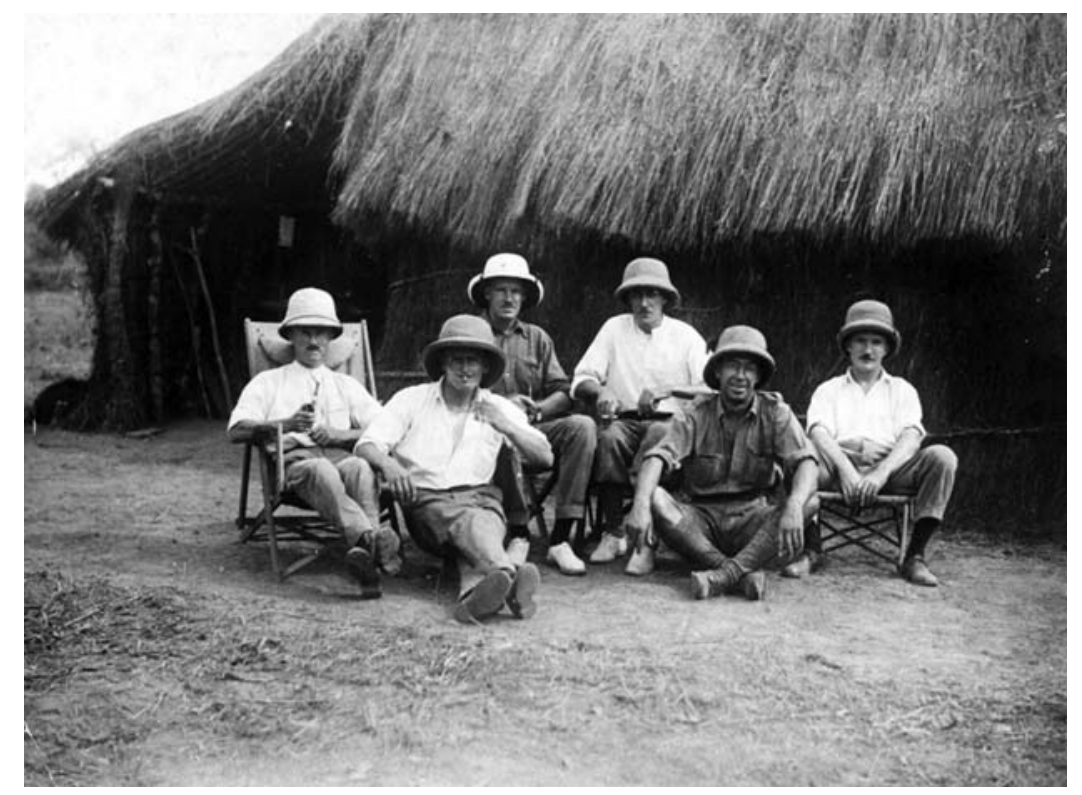

Figure 5. British workers in Nigeria in 1922 all wearing the solar topi. Source: W.F. Hackman in the National Archive UK Flickr Project.

understanding that was impossible for individual medical and hygiene experts who based their studies on single experiments conducted directly by the researcher, and who operated without a control provided by a larger network, to achieve.

In terms of construction, military barracks were the main field of experimentation for British colonizers in the mid-XIXth century: medical prescriptions were the theoretical basis for model residences produced in England and modified and adapted to the different areas of the British Empire. The article 'On the Construction of Barracks in Tropical Climate', published by captain John Smyth in the Papers on Subjects Connected with the Duties of the Corps of Royal Engineers in 1838, shows examples of hybridization between Western construction technologies and tropical climatic devices. The article illustrates the construction of barracks in the West Indies and opens with a significant statement on the process of adaptation to regional conditions:

The attention of the Corps has been much called of late years to the architectural requirements of convenience, strength and durability but I do not think that sufficient attention has been given to vary the construction according to the varying circumstances of climate and situation, and a general uniform system has been too much followed, not adapted to the many cases to which it has been applied. ${ }^{59}$

The barracks show the systematisation of the construction processes and the introduction of new materials that addressed climatic stresses (Figure 6). ${ }^{60}$

In 1861, the Barrack and Hospital Improvement Commission ${ }^{61}$ was created to examine the conditions of buildings in England and improve their design. Two similar commissions were established in the following years - one for the Mediterranean and one for tropical areas. The purpose of the commission was to identify the fundamental principles to ensure the health of

\footnotetext{
${ }^{59}$ Smyth, On the Construction of Barracks in Tropical Climate, 233.

${ }^{60}$ Weiler, "Royal Engineers and Building Technology Transfer in the XIX Century."

${ }^{61}$ Barrack and Hospital Improvement Commission, General Report of the Commission.
} 

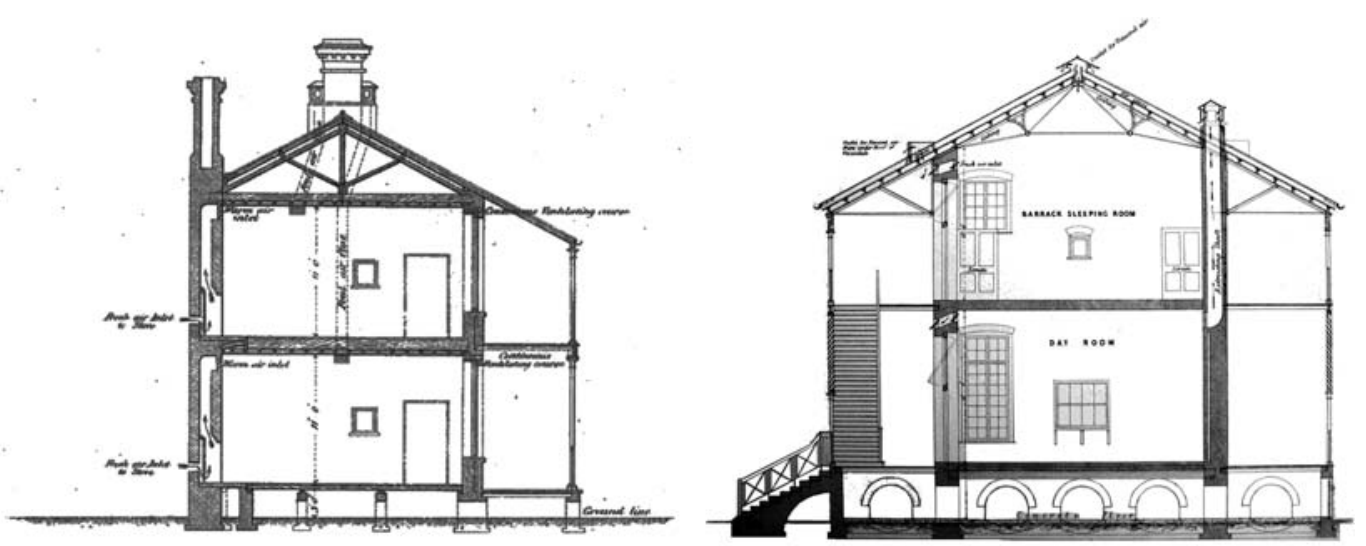

Figure 6. Model Barracks for the Mediterranean region (left) and the Tropical areas (right). Source: Barrack and Hospital Improvement Commission, General Report of the Commission (London: George Edward Eyre and William Spottiswoode, 1861).

structures as well as the parameters for the adaptability of principles to different climates. The comparison between the barracks proposed for the Mediterranean and the tropical climates shows the proposed adaptations to different climatic data. Both have a symmetrical plan with a central staircase and extensive use of windows to maximize ventilation. The fundamental difference, in addition to the different ventilation devices used, was the presence of a veranda in the Mediterranean model and a double veranda on both sides in the tropical one. The most interesting aspect, however, was the size of the buildings that varies in different conditions according to strict numerical standards ${ }^{62}$ : the English model had a 60 square feet area and a 600 cubic feet volume, the Mediterranean 70 and 750, the tropical 80 and 1500. Having assumed the basic principles that ensure the occupants' health, rigid numerical data were used to modify the buildings' internal heights and size and adapt them to different climates. The principles underlined by the Barrack and Hospital Improvement Commission were officially codified in the Barrack Synopsis ${ }^{63}$ of 1865, a document that would remain crucial in the construction of British military buildings until the mid-XXth century. Although varying in standards, all subsequent editions of the Barrack Synopsis showed the same strict classificatory logic dividing the three models into British, subtropical and tropical. All the various editions shared a strict division in standard models and a strenuous pursuit of objectivity.

In 1906, the Colonial Secretary Victor Bruce wrote to the governors of Sierra Leone, Gambia, the Gold Coast, Lagos and Northern Nigeria to investigate the housing conditions of British soldiers and civilians in West Africa. The census ended in 1909 with the publication of the book Design of Bungalows Provided for Government Officials in West Africa, a complete description of existing buildings and a set of guidelines for future constructions. The design process in tropical areas had become transnational: the birth of completely standardized building types reduced local design to the slavish application of a set of rules. The transnational character of building types was due both to the presence of a central hub in England and to the continuous movement of officers within the different tropical colonies. Victor Bruce had been the Viceroy of India during the 1890s; F.D.

\footnotetext{
${ }^{62}$ Chang and King, "Towards a Genealogy of Tropical Architecture," 288.
}

${ }^{63}$ War Office, Barrack Synopsis. 
Lugard, ${ }^{64}$ Governor of Northern Nigeria, had served in the Indian Army; and Walter Egerton, Governor of Lagos, had served in Malaysia for 23 years. The building types were the product of a collective experience that evolved over nearly two centuries within the British civil and military institutions. The refinement of construction techniques, exposure to local materials and on-site experience could perhaps generate better architectural and urban solutions, but the very nature of colonial networks did not admit any major modifications.

The hierarchical rigidity is perfectly represented by the description of the bungalows built at Fort Christiansborg in Ghana around 1915:

Four types of two-storey bungalows: for senior officers (married or single), junior officers (married), junior bachelors and up-country quarters. For the higher ranks, the ground floor contained dining room, store room, pantry and box room; the first floor, a sitting room, 2 bedrooms, 2 mosquito rooms, 2 bathrooms, 1 or 2 earth closets, 1 kiosk and an 8 foot veranda, outbuildings included a kitchen, lamp room, boys room, forage room, stables and drying closet. ${ }^{65}$

The permanence of building types is demonstrated by the forced adaptation of traditional forms or construction materials such as in the 'New Barracks built in Calabar' of $1909^{66}$ with a large roof that re-interprets traditional local architecture (Figure 7) or the 'Type Mud brick European Quarters' in Katsina, and the 'House for the British Resident' in Kano, from the 1930s, ${ }^{67}$ made with traditional earth construction techniques of the local Hausa people. The strongly typological approach, based on a rigid system of measurements, did not admit any modification resulting from different construction techniques; each single internal element was defined by non-negotiable dimensional parameters with the final result of a building shaped in the same way as the ones in imported materials. While the rigidity of the parameters made it possible to process numerous buildings quickly, it prevented any possible further design development; the blind faith in science had substituted hypochondriac fears as a major shapers of buildings and urban spaces, but the use of experimental tools as adaptable form factors within the design process was far from achieved.

\section{Towards qualitative processes: tropical building division}

A further step towards the definitive end of hypochondria and the establishment of scientific knowledge as a tool for design came from the Colonial Development Act of 1929 and the Colonial Development Welfare Act of 1940 that marked a radical change of attitude within British colonialism. ${ }^{68}$ The Colonial Development Welfare Act was the first law in which colonizers pledged to use resources from the central state for programmes aimed at raising the standard of living through extensive technology transfer. Resources were directed to basic needs such as housing, water supply, schools, social projects and infrastructure, with the idea that better services would produce a healthier and more efficient workforce, and above all a more predictable and less combative one. ${ }^{69}$ In terms of construction, the Colonial Development Welfare Act brought the establishment of the Colonial Housing Research Group in 1945. The huge growth in urban population between 1920 and 1940 had made African cities overcrowded and hygienically dangerous. However, the colonizers intended to remedy this with the latest technological tools at their disposal. The Colonial

\footnotetext{
${ }^{64}$ Lugard, The Dual Mandate in British Tropical Africa.

${ }^{65}$ King, The Bungalow 1600-1980, 304.

${ }^{66}$ Colonial Office, Design of Bungalows Provided for Government Officials.

${ }^{67}$ Yemi Salami, "British Colonial Architecture: Current Research Exports Only?" in Transnational Architecture Group, https:// transnationalarchitecturegroup.wordpress.com/2013/04/02/british-colonial-architecture-current-research-3/

${ }^{68}$ Pearce, The Turning Point in Africa, 4.

${ }^{69}$ Cooper, Africa since 1940, 31.
} 


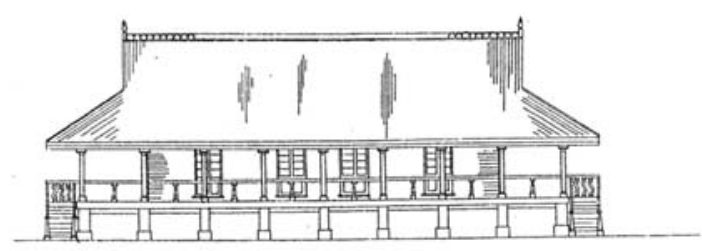

FRONT ELEVATION

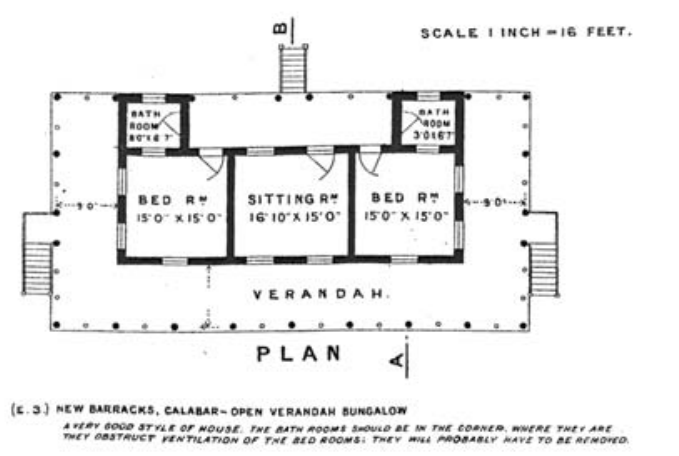

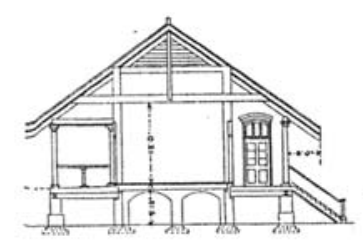

SECTION ON LINE A.B
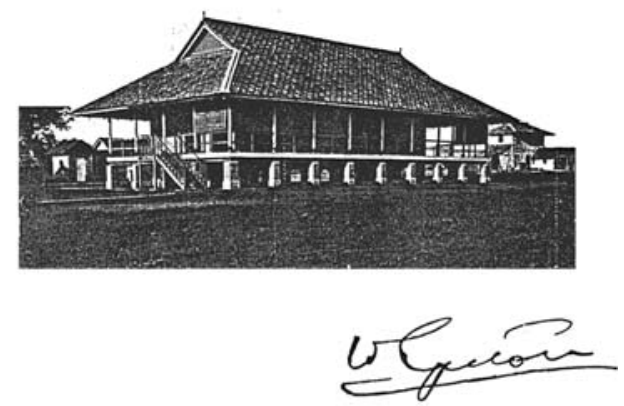

Figure 7. New Barracks in Calabar Nigeria from Colonial Office, Design of Bungalows provided for government officials (London: Colonial Office, 1909).

Housing Research Group put forward two requests: the creation of a main centre that would gather and disseminate information about colonial housing problems and of four peripheral research centres located in tropical areas. The main centre had to be based in London and serve as a repository where 'type plans, reports on various materials and on the performance, cost and suitability from various points of view of various designs might be accumulated and be available for consultation'. The four research centres were to be located in the West Indies, Malaysia, East Africa and West Africa and to act as data gathering and experimentation sites. Despite the changed goals, from the climatic adaptation of European colonizers to local community development, the strong central-peripheral logic persisted even during the decolonization process. Science remained an exclusive prerogative of the metropolitan centre, while the colonies were sites for experiments on applied sciences. ${ }^{70}$

From a methodological point of view, the work of the Colonial Housing Research Group followed the method used in the same years to address malnutrition in the colonies. Malnutrition was seen as a problem unrelated to the wider picture of socio-economic and poverty conditions ${ }^{71}$ that could be addressed by medical experts and nutritionists without changing the structural and historical conditions that led to poverty. Likewise, the problem of constructions could be solved through the study of physical and material aspects, ${ }^{72}$ and technical developments would be sufficient to provide everyone with decent housing. The programme was doomed to fail: the strictly

\footnotetext{
${ }^{70}$ Cooper and Packard, International Development and the Social Sciences, 65.

${ }^{71}$ Worboys, "The Discovery of Colonial Malnutrition Between the Wars," 208-35.

${ }^{72}$ Chang, "Building a Colonial Techno-Scientific Network," 215.
} 
quantitative process that had been successful within the Royal Engineers was not applicable at a global scale without a mediation with economic and social issues.

In postwar years the renewed interest in colonies that were soon to become independent states allowed the development of independent and free research in tropical areas. The Colonial Research Committee was established in 1940 and subdivided into disciplinary committees, one of which specifically for construction. The committees introduced flexible arrangements for the exchange of researchers with the revolutionary idea of creating a reserve of scientific workers that were believed to be true 'global experts'. During the following two decades, the different Colonial and Development Welfare Acts promoted research activities in many fields: construction, agriculture, animal industry, biology, fishing, forestry, medicine and social sciences. ${ }^{73}$

In June 1948, George Atkinson was appointed as Colonial Liaison Officer with the task of overseeing the global collection, organization and dissemination of data and information regarding buildings in the British colonial world. ${ }^{74}$ Atkinson, who had worked during the war in West Africa, North Africa and the Middle East on behalf of the RAF, received the task of defining minimum standards for buildings in the tropics, with special regard to construction costs. The Colonial Office intended to establish performance calculations and design methods specific to tropical areas, no longer standard projects such as barracks or bungalows. According to Frederick Lea, the director of the Building Research Station between 1946 and 1965, the use of scientific methods could be applied systematically to overcome the limits of the construction industry, still based on semi-craft processes based on empirical evidence and errors. ${ }^{75}$

The use of scientific methods applied to buildings had two main objectives: the predictability of performance and the replicability in different areas and contexts. While the standards were designed to reach the maximum degree of dissemination, they had to remain constant while circulating in different contexts (building research stations, construction industries, design firms, construction sites) and being used by different professionals (architects, contractors, engineers, technology experts). Identifying qualitative standards led to the creation of a network in which heterogeneous elements could find a synthesis. The network created by Atkinson used diagrams and tables as its main tools. It longer relied on closed dimensional prescriptions but on calculation systems that, in the hands of different professionals, could generate different constructive and architectural solutions, allowing a scientific control of each phase of the project. Thanks to this open approach, the Tropical Building Division network subverted the rigid central-periphery relationship and became a truly transnational network. ${ }^{76}$ The metropolitan centre was still responsible for the creation of analytical systems but every peripheral node was required to adapt and improve the received system and the information no longer came as strict dogmas but as indications, the beginning, not the end, of the design process.

In the post-war period, architects began to be considered as planners, territorial managers and controllers of the construction process. The use of Atkinson's tools led to a mature technology transfer that was not limited to

The traditional brick-tile-and-timber methods of construction, which are still forming the basis of English buildings side by side with the gaily painted earth walls and carved woodwork tradition. At all costs we must avoid attempting to reproduce in modern materials the forms and patterns of some local style. $^{77}$

\footnotetext{
${ }^{73}$ Jeffries, A Review of Colonial Research 1940-1960.

${ }^{74}$ Atkinson, "Thoughts During the Building Research Establishment's 75th Anniversary," 101-8.

${ }^{75}$ Lea, Science and Building: A History of the Building Research Station.

${ }^{76}$ Rand, "Transnational Dialogues: Antoinette Burton and the Rewritings of British Imperial History."

${ }^{77}$ Atkinson, "British Architects in the Tropics," 13.
} 
The network and design method set up by Atkinson were publicized in numerous technical and architectural magazines. ${ }^{78}$ Additionally, they were presented in a specific publication: Colonial Building Notes, which in 1958 was renamed Overseas Building Notes. The journal, published at irregular intervals, collected articles on various subjects summarized in three main areas: models of buildings or urban plans, experiments on building materials and construction methods and climate design with a particular focus on the issues of shadowing, ventilation and thermal comfort. The Tropical Building Division worked closely with the British architects in the tropical areas, verifying the performance levels of the buildings, ${ }^{79}$ and with local universities, advising study plans and research themes. ${ }^{80}$ The relationship between Western professionals and tropical areas had reached such a high degree of maturity that it was able to allow processes of exportation and modification of technologies adapting to local climatic conditions.

\section{Conclusion: tropical architecture, the end of hypochondria?}

The emergence of Tropical Architecture in the postwar years, with the work of numerous British firms in West Africa such as Fry\&Drew, Architects Co-Partnership, James Cubbitt and partners, Godwin\&Hopwood and Nickson\&Borys, within the framework of planned decolonization ${ }^{81}$ and the slow passage of powers from colonial powers to newly independent nations, is perhaps one last step towards the definitive construction of tropical area design approaches that were freed from hypochondria. The conceptualization of such an attitude was inherent in the manual Tropical Architecture in the Dry and Humid zones ${ }^{82}$ and which was published by Edwin Maxwell Fry and Jane Drew in two similar versions in 1956 and 1964. The manual, which showed the willingness to establish a design system specially adapted to tropical areas, was the effort of two pioneers who imagined that a scientific and technocratic approach could reconcile modernism with the conditions of underdevelopment. ${ }^{83}$ A regionalist design system that, while strongly rooted in climatic and geographic features, was at the same time an anti-localist one, removed from any type of anxiety or hypochondria, any vernacular tradition and any claim of cultural analysis.

The text was a conceptualization of the numerous architectural and urban designs produced in the late 50s in West Africa and which aimed at highlighting influences and relationships. The introduction clearly states its intent:

We write $[\ldots]$ for the growing number of those who inhabit these regions [...]. On these architects and planners falls the major burden of creating an environment in which the tropical people may flourish. (..) So will the future architects who build for their own tropical people bring to their tasks, emotions, sympathies and knowledge denied to us who come from outside. ${ }^{84}$

This dedication represents a clear break in the long history of colonial relationships: it acknowledges the colonial character of the European presence in Africa and the long and troubled colonial history, but at the same time it distances the authors from previous experiences by individuating the locals as the protagonists of future development. Only by incorporating local experiences in design choices would it become possible to definitely overcome hypochondria, in a long

\footnotetext{
${ }^{78}$ Atkinson, "Principles of Tropical Design."

${ }^{79}$ Robinson, "Towards a Tropical Architecture."

${ }^{80}$ Wilton, "Una scuola di architettura africana."

${ }^{81}$ Flint, "Planned Decolonization and Its Failure in British Africa."

${ }^{82}$ Fry and Drew, Tropical Architecture in the Humid Zone; Fry and Drew, Tropical Architecture in the Dry and Humid Zones.

${ }^{83}$ Crinson, Modern Architecture and the End of Empire, 132-7.

${ }^{84}$ Fry and Drew, Tropical Architecture in the Dry and Humid Zones, 17-18.
} 


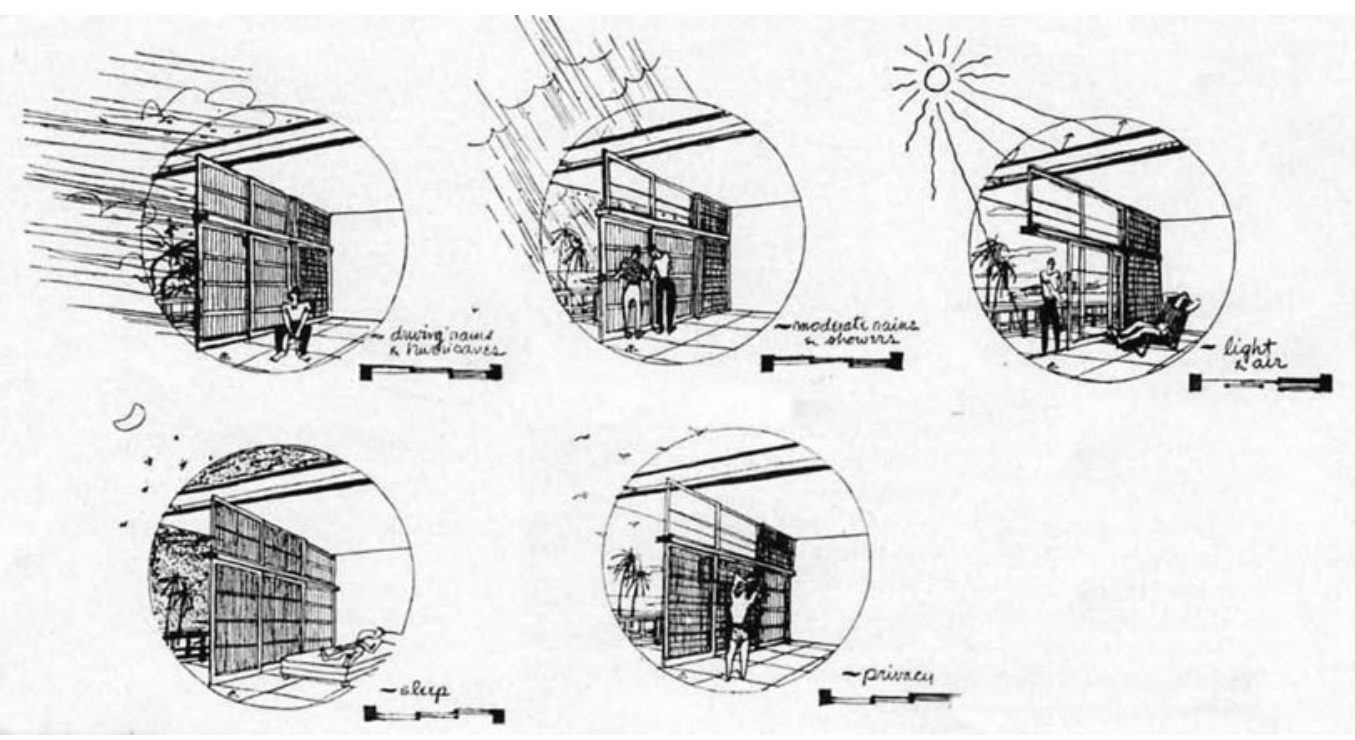

Figure 8. Schemes summarizing the relationships with climatic conditions. Source: Edwin Maxwell Fry, Jane Drew, Tropical Architecture in the Dry and Humid zones (London: Batsford, 1964). p. 63.

decolonization process that was in many ways still ongoing. ${ }^{85}$ This, nevertheless, marked a significant break in this important cultural shift (Figure 8).

The work of the designers of Tropical Architecture was a definitive attempt to overcome hypochondria by exploring the importance of cultural affiliation to local societies, and the ability to understand subconscious desires and future changes. The final aim of the manual was the identification of a design method equipped with a firm techno-scientific rooting within the indigenous context. A design method that reduces the context to a series of data and does not provide fixed solutions but rather open design tools applicable with different forms and means by each designer. A design approach that effectively eliminates any localism or irrational anxiety; an approach respectful of resources and seeking to construct a new modernity or another modernity that, from tropical areas, can aspire to a universal value. Despite such major improvements hypochondria did not completely disappear from the construction of buildings and cities in the former British Empire. The idea of a clear division between local population and colonizers was so embedded in colonial culture that even when constructing a school system for the training of future postcolonial local elites the designers of Tropical Architecture decided, perhaps for subconscious reasons, to clearly divide the new citadels of culture from the main urban areas and define spaces that could defend the young post-colonial leaders from the dangers and seductions of the emergent African metropolis. $^{86}$

Tropical Architecture is a symptom of a larger phenomenon in the colonial experience after World War 2: the acceptance of the necessity to conclude the complete occupation of the territory and transform the relationship in a form of economic and cultural exchange. This idea was received with varying levels of resistance by different countries ${ }^{87}$ : Portugal resisted independence until the

\footnotetext{
${ }^{85}$ Enwezor, The Short Century.

${ }^{86}$ Lagae, "Montcassin, Montserrat or ... An Alcazar'?," 277-94.

${ }^{87}$ Cardoso Reis, "Myths of Decolonization."
} 
middle of the 70's using colonial affairs as a mean to represent a faded imperial glory, ${ }^{88}$ France attempted, but failed, to construct a union based on shared key cultural aspects, ${ }^{89}$ while Britain opportunistically transformed the Empire into the Commonwealth, through subtle diplomatic work consisting of economic concessions and symbolic gestures. ${ }^{90}$

Within this framework architecture and urban planning became key elements in the construction of a new relationship between the former colonizer and colonized: the hyper monumental style of Portuguese Gabinete de Urbanização do Ultramar, ${ }^{11}$ the contemporary casbahs of French vernacular modernism, ${ }^{92}$ and the contextual modernism of Tropical Architecture become different manifestos of approaches intended to construct a new system of relationships apparently freed from previous fears and hypochondria. In the long and perilous decolonization process the general focus shifted towards mass housing, ${ }^{93}$ a process that was seen as a tool capable of raising the standard of living of local populations. The debate mainly focused on speed of production and appropriate building technologies. This shift made the focus on hygiene and climatic adaptation less important: the new spaces to be designed and constructed were not intended for Europeans but for an emerging local middle class that, in yet another example of the persistence of hypochondria as a racial dividing line, were seen as less interested in climatic solutions.

\section{Disclosure statement}

No potential conflict of interest was reported by the author(s).

\section{Notes on contributor}

Jacopo Galli (Crema, 1985) obtained his PhD from Università Iuav di Venezia with a dissertation on the African works of Edwin Maxwell Fry and Jane Drew that was published in the book Tropical Toolbox. He was among the curators of the exhibition Africa Big Change - Big Chance in La Triennale Milan and CIVA Bruxelles (2015). He was the author of a book devoted to the Ethiopian works of Arturo Mezzedimi and has been part of international exhibition (Biennale di Venezia, Triennale di Milano) and workshops (Virginia University Venice Program, Rebulding Syria from Within, WAVE 2017 Syria the Making of the Future). He is among the founders of Urbicide Task Force, a multidisciplinary think tank on architectural and urban reconstruction strategies, that is a consultant for the World Bank programme Building for Peace in MENA.

\section{ORCID}

Jacopo Galli (D) http://orcid.org/0000-0001-8494-9990

\section{Bibliography}

Amaral, Isabel. "The Emergence of Tropical Medicine in Portugal: The School of Tropical Medicine and the Colonial Hospital of Lisbon (1902-1935).” Dynamis 28 (2008): 301-328.

American Psychological Association. Diagnostic and Statistical Manual of Mental Disorders. 4th ed. Washington DC: American Psychiatric Association Publishing, 1994.

\footnotetext{
${ }^{88}$ MacQueen, The Decolonization of Portuguese Africa.

${ }^{89}$ Smith, "Future Imperfect: Colonial Futures, Contingencies and the End of French Empire."

${ }^{90}$ See Huxley and Deane, The Future of the Colonies.

${ }^{91}$ See Tostões, Modern Architecture in Africa; Magalhães, "Modern Movement Migrations."

${ }^{92}$ See Dubor, Fernand Pouillon Architetto delle 200 colonne; Cohen and Eleb, Casablanca: Colonial Myths and Architectural Ventures; Dousson, Jean Bossu: Une trajectoire moderne singulière.

${ }^{93}$ See Demissie, Postcolonial African Cities; Rüther et al., The Politics of Housing in (Post-)Colonial Africa.
} 
Atkinson, George. "British Architects in the Tropics." Architectural Association Journal (1953): 7-21.

Atkinson, George. "Principles of Tropical Design." Architectural Review 128 (1960): 81-83.

Atkinson, George. “Thoughts During the Building Research Establishment's 75th Anniversary." Construction History 12 (1996): 101-108.

Barrack and Hospital Improvement Commission. General Report of the Commission. London: George Edward Eyre and William Spottiswoode, 1861.

Barrett, Frank. "The Role of French-Language Contributors to the Development of Medical Geography (1782-1933)." Social Science \& Medicine 55, no. 1 (2002): 155-165.

Blackman, Robert James. Aids to Tropical Hygiene. London: Bailliere, Tindall and Cox, 1912.

Bowdich, Thomas Edward. Mission from Cape Coast Castle to Ashantee. London: Griffith \& Farran, 1819.

Boyle, James. A Practical Medico-Historical Account of the Western Coast of Africa Embracing a Topographical

Description of Its Shores, Rivers and Settlements with their Seasons and Comparative Healthiness Together with the Causes, Symptoms and Treatment of the Fevers of Western Africa and a Similar Account Respecting the Other Disease which Prevail There. London: S. Highley, 1831.

Brásio, António. Monumenta Missionaria Africana. Lisbon: Agência Geral do Ultramar, 1952.

Buchanan, R. A. “The Diaspora of British Engineering." Technology and Culture 27, no. 3 (1986): 501-524.

Cairns, H. A. Prelude to Imperialism. London: Routledge, 1965.

Cardoso Reis, Bruno. "Myths of Decolonization: Britain, France, and Portugal Compared." In The End of European Colonial Empires, edited by Miguel Bandeira Jeronimo, and Antonio Costa Pinto, 126-147. London: Palgravre Mcmillan, 2015.

Chang, Jiat-Hwee. "Building a Colonial Techno-Scientific Network: Tropical Architecture, Building Science and the Politics of Decolonization." In Third World Modernism, Architecture, Development and Identity, edited by Dunfang Lu, 211-235. London-New York: Routledge, 2011.

Chang, Jiat-Hwee, and Anthony King. "Towards a Genealogy of Tropical Architecture: Historical Fragments of Power-Knowledge, Built Environment and Climate in the British Colonial Territories." Singapore Journal of Tropical Geography 32 (2011): 283-300.

Cohen, Jean-Louis, and Monique Eleb. Casablanca: Colonial Myths and Architectural Ventures. New York: Monacelli Press, 2002.

Colonial Office. Design of Bungalows Provided for Government Officials. London: Colonial Office, 1909.

Cooper, Frederick. Africa since 1940: The Past of the Present. Cambridge: Cambridge University Press, Cambridge, 2002.

Cooper, Frederick, and Randall Packard. International Development and the Social Sciences: Essays on the History and Politics of Knowledge. Berkeley-Los Angeles: University of California Press, 1990.

Crozier, Anna. "What Was Tropical about Tropical Neurasthenia? The Utility of the Diagnosis in the Management of British East Africa." Journal of the History of Medicine and Allied Sciences 64, no. 4 (2009): 518-548.

Crinson, Mark. Modern Architecture and the End of Empire. Farnham: Ashgate, 2003.

Curtin, Philip. Disease and Empire: The Health of European Troops in the Conquest of Africa. Cambridge: Cambridge University Press, 1998.

Curtin, Philip. “The White Man's Grave': Image and Reality, 1780-1850.” Journal of British Studies 1 (1961): 94-110.

Dapper, Olfert. Naukeurige beschrijvinge der Afrikaensche Eylanden. Amsterdam: Jacob van Meurs, 1668.

de Souza Correa, Sílvio Marcus. "Combating Tropical Diseases in the German Colonial Press." Historia, Ciencias, Saude Manguinhos 20, no. 1 (2013). doi:10.1590/S0104-59702013005000003.

Demissie, Fassil. Postcolonial African Cities: Imperial Legacies and Postcolonial Predicament. New York: Routledge, 2007.

Dousson, Xavier. Jean Bossu: Une trajectoire moderne singulière. Paris: Editions du Patrimoine, 2014.

Dubor, Bernard Félix. Fernand Pouillon Architetto delle 200 colonne. Milan: Electa, 1987.

Driver, Felix, and Luciana Martins. Tropical Vision in the Age of Empire. Chicago: University of Chicago Press, 2005.

Ellingson, Ter. The Myth of the Noble Savage. Berkeley: University of California Press, 2001.

Enwezor, Okwui. The Short Century: Independence and Liberation Movements in Africa 1945-1994. MunichLondon-New York: Prestel Verlag, 2001.

Fanon, Frantz. Le damnes de la terre. Paris: Maspero/Le Decouverte \& Syros, 1961.

Farley, John. Bilharzia: A History of Imperial Tropical Medicine. Cambridge: Cambridge University Press, 1991. 
Flint, John. "Planned Decolonization and Its Failure in British Africa." African Affairs 82, no. 328 (1983): 389-411. Fry, Edwin Maxwell, and Jane Drew. Tropical Architecture in the Humid Zone. London: Batsford, 1956.

Fry, Edwin Maxwell, and Jane Drew. Tropical Architecture in the Dry and Humid Zones. London: Batsford, 1964.

Greenwood, Anna. “Looking Back: The Strange History of Tropical Neurasthenia.” The Psychologist 24 (2011): 226-227.

Harrison, Mark. Climates and Constitutions: Health, Race, Environment and British Imperialism in India 1600-1850. New Delhi: Oxford University Press, 1999.

Headrick, Daniel. The Tentacles of Progress, Technology Transfer in the Age of Imperialism 1850-1940. Oxford: Oxford University Press, 1988.

Hodges, Sarah. “The Global Menace.” Social History of Medicine 25, no. 3 (2012): 719-728.

Hodges, William. Travels in India during the Years 1780, 1781, 1782, \& 1783. London: J. Edwards, 1793.

Huxley, Elsepth. Out in the Midday Sun. London: Harmondsworth, 1987.

Huxley, Julian, and Phyllis Deane. The Future of the Colonies. London: Pilot Press, 1944.

Jeffries, Charles. A Review of Colonial Research 1940-1960. London: H.M. Stationery Office, 1964.

Johnson, Ryan. "European Cloth and 'Tropical' Skin: Clothing Material and British Ideas of Health and Hygiene in Tropical Climates." Bulletin of the History of Medicine 83, no. 3 (2009): 530-560.

Jones, Adam. “Decompiling Dapper: A Preliminary Search for Evidence.” History in Africa 17 (1990): 171209.

Kennedy, Dane. "Diagnosing the Colonial Dilemma: Tropical Neurasthenia and the Alienated Briton." In Decentering Empire: Britain, India, and the Transcolonial World, edited by Dane Kennedy, and Durba Ghosh, 157-181. Hyderabad: Orient Longman, 2006.

Kennedy, Dane. Islands of White: Settler Society and Culture in Kenya and Southern Rhodesia, 1890-1939. Durham, NC: Duke University Press, 1987.

Kennedy, Dane. "The Perils of the Midday Sun: Climatic Anxieties in the Colonial Tropics." In Imperialism and the Natural World, edited by John MacKenzie, 118-140. Manchester: Manchester University Press, 1990.

Kenny, Judith. "Climate, Race, and Imperial Authority: The Symbolic Landscape of the British Hill Station in India." Annals of the Association of American Geographers 85 (1995): 694-714.

Kidd, Benjamin. The Control of the Tropics. New York: MacMillan, 1898.

King, Anthony. The Bungalow 1600-1980. A Study of the Cultural, Social, Political and Economic Factors in the Production of a Global House-Type. Brunel University, PhD Thesis, 1982.

King, Anthony. The Bungalow: The Production of a Global Culture. London: Routledge, 1984.

Lagae, Johan. "Montcassin, Montserrat or ... An Alcazar'? Architecture, Propaganda and Everyday School Practices in the Collège du Saint-Esprit in Bujumbura." In Colonial Architecture and Urbanism in Africa: Intertwined and Contested Histories, edited by Fassil Demissie, 277-294. Farnham: Ashgate, 2012.

Lea, Frederick. Science and Building: A History of the Building Research Station. London: Building Research Station, 1971.

Lind, James. An Essay on Diseases Incidental on Europeans in Hot Climates. Philadelphia: William Duane, 1811.

Lugard, Frederick. The Dual Mandate in British Tropical Africa. London: Frank Cass \& Co. Ltd., 1922.

Mabuce, Ethel. I Always Wore My Topi. Burma Letters, 1916-21. Tuscaloosa, AL: University of Alabama Press, 1974.

MacKenzie, John. Imperialism and the Natural World. Manchester: Manchester University Press, 1990.

MacQueen, Norrie. The Decolonization of Portuguese Africa: Metropolitan Revolution and the Dissolution of Empire. London: Longman, 1997.

Macleod, Roy, and Milton Lewis. Disease, Medicine, and Empire: Perspectives on Western Medicine and the Experience of European Experience. London: Routledge, 1988.

Magalhães, Ana. "Modern Movement Migrations: Architecture in Angola and Mozambique (1948-1975)." Athens Journal of Architecture 4, no. 1 (2018): 31-52.

Manson, Patrick. Tropical Diseases; a Manual of the Diseases of Warm Climates. London: Cassell, 1898. Moseley, Benjamin. Treatise on Tropical Diseases on Military Operations. London: Nichols and Son, 1804. Moseley, Benjamin. Medical Tracts. London: T. N. Longman and O. Rees, 1804.

Murray, John. How to Live in Tropical Africa. London: Philip \& Son, 1895.

Osborne, Michael. The Emergence of Tropical Medicine in France. Chicago: University of Chicago Press, 2015. 
Pearce, Robert. The Turning Point in Africa. British Colonial Policy 1938-1948. London: Frank Cass, 1982. Pelling, Margaret. "The Meaning of Contagion: Reproduction, Medicine and Metaphor." In Contagion: Epidemics, History and Culture from Smallpox to Anthrax, edited by Alison Bashford, and Claire Hooker, 15-38. Sydney: Pluto Press, 2002.

Pruem, Tristem. The Arab and the African. London: Seeley and Co., 1891.

Rand, Gavin. "Transnational Dialogues: Antoinette Burton and the Rewritings of British Imperial History." Journal of Victorian Culture 17, no. 3 (2012): 385-389.

Rankin, Harrison. The White Man's Grave: A Visit to Sierra Leone, in 1834. London: R. Bentley, 1836.

Renbourn, E. T. "The History of the Flannel Binder and Cholera Belt." Journal of Medical History 1, no. 3 (1957): 211-225.

Robinson, D. C. "Towards a Tropical Architecture: The Work of Architects Co-Partnership in Nigeria." Architectural Design 4 (1959): 128-140.

Rüther, Kirsten, Martina Barker-Ciganikova, Daniela Waldburger, and Carl-Philipp Bodenstein. The Politics of Housing in (Post-)Colonial Africa: Accommodating Workers and Urban Residents. Berlin: De Gruyter, 2020.

Ryan, Charles. Health Preservation in West Africa, John Bale. London: Sons \& Danielsson, 1914.

Said, Edward. Orientalism. New York: Vintage Books, 1978.

Sambon, Luigi. "Remarks on the Possibility of the Acclimatisation of Europeans in the Tropical Regions." British Medical Journal 1 (1897): 66.

Savage, Victor. Western Impression of Nature and Landscape in Southeast Asia. Singapore: Singapore University Press, 1984.

Simpson, William John Ritchie. The Maintenance of Health in the Tropics. London: John Bale, Sons \& Danielsson, 1916.

Smith, Andrew. "Future Imperfect: Colonial Futures, Contingencies and the End of French Empire." In Britain, France and the Decolonization of Africa: Future Imperfect?, edited by Andrew Smith, and Chris Jeppesen, 87-110. London: UCL Press, 2017.

Smith, Cameron. The History of Tropical Medicine. Sydney: Sydney University Press, 2012.

Smyth, John. On the Construction of Barracks in Tropical Climate in Papers on Subjects Connected with the Duties of the Corps of Royal Engineers. London: Barker, 1838.

Stoddard, Theodore. The Rising Tide of Color against the White World Supremacy. New York: Charles Scribner's \& Sons, 1921.

Teichfischer, Philipp. "Transnational Entanglements in Colonial Medicine German Medical Practitioners as Members of the Health Service in the Dutch East Indies (1816-1884)." History, Medicine and Health 10 (2010): 63-78.

Tilley, Hellen. Africa As a Living Laboratory: Empire, Development, and the Problem of Scientific Knowledge, 1870-1950. Chicago: University of Chicago Press, 2011.

Tilley, Hellen. "Medicine, Empires, and Ethics in Colonial Africa." History of Medicine (2016). doi:10.1001/ journalofethics.2016.18.7.mhst1-1607.

Tostões, Ana. Modern Architecture in Africa: Angola and Mozambique. Lisbon: ICIST, Técnico, 2013.

War Office, Office of the Director of Fortifications and Works. Barrack Synopsis. London: H.M.S.O. by Harrison and Sons, 1904.

Warwick, Anderson. The Cultivation of Whiteness: Science, Health, and Racial Destiny in Australia. Melbourne: Melbourne University Press, 2003.

Warwick, Anderson. Colonial Pathologies: American Tropical Medicine, Race and Hygiene in the Philippines. Durham, NC: Duke University Press, 2006.

Weiler, John Michael. Army Architects, The Royal Engineers and the Development of Building Technology in the Nineteenth Century. York University, PhD Thesis, 1987.

Weiler, John Michael. "Royal Engineers and Building Technology Transfer in the XIX Century." Construction History 12 (1996): 3-18.

Wilton, Graham. "Una Scuola di Architettura Africana.” Edilizia Moderna 89-90 (1966): 39-51.

Woodruff, Charles Edward. The Effects of Tropical Light on White Man. New York: Rebman Company, 1905.

Worboys, Michael. "The Discovery of Colonial Malnutrition Between the Wars." In Imperial Medicine and Indigenous Societies, edited by David Arnold, 208-235. Manchester: Manchester University Press, 1988. 